\title{
Does Causality Technique Matter to Savings-Growth Nexus in Malaysia?
}

\author{
CHOR FOON TANG \\ School of Social Sciences \\ Universiti Sains Malaysia
}

\begin{abstract}
The intention of this study was to investigate whether the causal inference between savings and economic growth in Malaysia is sensitive to the particular causality tests employed to ascertain the causal relationship. This study covered quarterly data from 1991:Q1 to 2006:Q3. The results suggested that the causal relationship between savings and economic growth in Malaysia is not sensitive to the particular causality test used. Thus, causality test plays no role in explaining the inconsistency causality result of savings and economic growth. Ultimately, causality test does not matter to savings-growth nexus for Malaysia.
\end{abstract}

Keywords: Causality; parametric; nonparametric; savings; growth. JEL Classification Code: C14; C22; E21; O16.

\begin{abstract}
ABSTRAK
Tujuan kajian ini dijalankan adalah untuk mengkaji sama ada hubungan sebab-penyebab antara tabungan dan pertumbuhan ekonomi di Malaysia adalah sensitif terhadap pendekatan yang digunakan untuk menentukan arah sebab-penyebab. Kajian ini menggunakan data sukuan dari tahun 1991:1 hingga 2006:3. Keputusan empirikal kajian ini mendapati bahawa hubungan sebab-penyebab antara tabungan dan pertumbuhan ekonomi di Malaysia tidak sensitif terhadap pendekatan sebab-penyebab yang digunakan. Justeru, pendekatan sebab-penyebab bukan penentu kepada ketidakserasian hubungan sebab-penyebab antara tabungan dan pertumbuhan ekonomi di Malaysia.
\end{abstract}

Kata kunci: Sebab-penyebab; parametrik; bukan parametrik; tabungan; pertumbuhan ekonomi. Klasifikasi Kod JEL: C14; C22; E21; O16.

\section{INTRODUCTION}

By the beginning of the 21st century, Malaysia had become one of the fastest growing economies in the Southeast Asian region. ${ }^{1}$ Various theoretical explanations have been provided by many researchers to understand the reason behind this impressive growth. One of the interesting areas that has not been provided with consensus evidence is the causal link between savings and economic growth. This causal relationship is also known as the savings-growth nexus. Many researchers have empirically investigated the causal link between savings and economic growth in Malaysia through various model specifications (Gruben \& McLeod, 1998; Agrawal, 2001; Baharumshah, Thanoon, \& Rashid, 2003). Unfortunately, previous empirical tests failed to produce clear evidence of the causal link. In view of literature, some empirical studies claimed that economic growth causes savings to 
change, (Sinha \& Sinha, 1998; Carroll, Overland, \& Weil, 2000; Rodrik, 2000; Baharumshah, et al., 2003), however others defended the view that savings induce economic growth through its impact on capital formation (Lewis, 1955; Levine \& Renelt, 1992; Mankiw, Romer, \& Weil, 1992; Agrawal, 2001; Alguacil, Cuadros, \& Orts, 2004; Tang, 2008). This controversial finding has sparked the interest of this study to further investigate the issue of savings-growth nexus in Malaysia from a different perspective.

Chowdury (1987) argued that in most cases the non-consensus causality result was probably attributed to the different causality tests employed. Thornton and Batten (1985) and $\mathrm{Xu}$ (1996) added that the arbitrariness in the choice of lag order for causality test may also yield different causality results. Moreover, Lee, Lin, and Wu (2002) conducted a Monte Carlo experiment to examine the performance of Granger causality test in detecting the true causal relationship. They pointed out that relying on one causality test may not be enough to identify the true causal relationship. As far as Malaysia is concerned, empirical studies for the savings-growth nexus are based on a single causality test to verify the causality direction for formulation and implementation of appropriate macroeconomics policies. For this reason, the policy suggestion based on one causality test is not without question. Therefore, the goal of this study is to re-investigate the causality direction between savings and economic growth in Malaysia through parametric and nonparametric causality testing procedures. ${ }^{2}$ By testing the causality direction with various methods, we were able to assess whether savings-growth nexus in Malaysia is sensitive to the particular causality test used in determining the causal relationship. To the best of our knowledge, none of the existing empirical studies has tested the role of causality techniques on the issue of savings-growth nexus. In addition to that, the findings of this study that are based on various causality tests provides a more reliable result to the policy maker, whether freeing up domestic resources such as savings is helpful or harmful to the Malaysian economy. This econometric exercise is parallel to the suggestion noted in Lee et al. (2002). If the causality evidence suggests that savings Granger causes economic growth, this reflects that the financial system in Malaysia successfully translates savings into capital formation which fosters economic growth. Otherwise, if economic growth is not the result of savings, policy initiatives that encourage savings could be detrimental to the economy.

The remainder of this article is set out as follows. Section will briefly discuss the data, model, and stationarity test. Section will shortly present the causality testing procedures use in this study. Section reports the empirical results and Section concludes.

\section{DATA, MODEL, AND STATIONARITY TEST}

\section{Data and Model}

This study uses quarterly data of gross domestic saving (GDS), gross domestic product (GDP), and consumer price index (CPI, $2000=100)$ from 1991:Q1 to 2006:Q3 in Malaysia extracted from International Monetary Fund (IMF) publication, International Financial Statistics (IFS) and Bank Negara Malaysia publication, Monthly Statistical Bulletin. The estimated variables are deflated by CPI to obtain the real terms. Quarterly data is used in this article in order to yield more power on statistical test and to avoid the size distortion problem (Zhou, 2001).

In this article, we use the bivariate savings function that relates to economic growth. The savings function can be written as:

$\ln S_{t}=\alpha+\beta \ln G_{t}+\varepsilon_{t}$

where $\ln S_{t}$ represents the natural log of real gross domestic saving $(R G D S)$ and $\ln G_{t}$ is the natural log of real gross domestic product (RGDP); $\varepsilon_{t}$ is an error term assumed to be white noise and complies to the classical assumption.

\section{Stationarity Test}

It is well known that the standard Augmented Dickey-Fuller (ADF) and Phillips-Perron (PP) tests have been criticised for having low power 
in distinguishing between unit root and a near unit root stationary process (Campbell \& Perron, 1991; DeJong, Nankervis, Savin, \& Whiteman, 1992). The low power of ADF and PP unit root tests has prompted the present study to use the null stationary test proposed by Kwiatkowski, Phillips, Schmidt and Shin (1992) - KPSS. The KPSS semi-parametric approach is to test the null hypothesis of level $\left(\eta_{\mu}\right)$ or trend $\left(\eta_{\tau}\right)$ stationarity against the alternative hypothesis of a unit root. The following expresses the KPSS test statistics equation,

$$
L M=\eta_{\mu}\left(\eta_{\tau}\right)=\frac{1}{s^{2}(k) T^{2}} \sum_{t=1}^{T} S_{t}^{2}
$$

where $S_{t}=\sum_{i=1}^{t} u_{i}, u_{t}$ are residuals from the OLS regression of $y_{t}$ on the exogenous variables $x_{t} \cdot s^{2}(k)$ is the nonparametric estimate of the long run variance of $u_{t}$ and $k$ represents for the lag truncation parameter.

\section{CAUSALITY TESTING PROCEDURES}

In this section, we briefly discuss the selected five causality testing procedures.

\section{Parametric Causality Techniques}

\section{Granger Test}

Since the standard Granger (1969) causality testing procedure has been widely used in earlier empirical studies, only a brief discussion is offered here. Causality in the Granger sense asserts that savings causes economic growth if the past values of savings can be used to forecast economic growth more accurately than just the past values of economic growth. Therefore, the Granger causality testing equation can be expressed as follows.

$$
\begin{aligned}
& \Delta \ln G_{t}=\alpha+\sum_{i=1}^{p} \delta_{i} \Delta \ln G_{t-i}+\sum_{j=1}^{q} \lambda_{j} \Delta \ln S_{t-j}+\varepsilon_{1 t} \\
& \Delta \ln S_{t}=\alpha+\sum_{i=1}^{p} \lambda_{i} \Delta \ln S_{t-i}+\sum_{j=1}^{q} \delta_{j} \Delta \ln G_{t-j}+\varepsilon_{2 t}
\end{aligned}
$$

where $\Delta$ is the first difference operator; $p$ and $q$ are the maximum lag order, and the residuals $\left(\varepsilon_{1 t}, \varepsilon_{2 t}\right)$ are assumed to be white noise and spherically distributed. The Granger causality test is implemented by computing the $F$-statistic on the lagged variables. From equation (3), $\lambda_{j} \neq 0 \forall{ }_{j}$ implies that there is causality running from savings to economic growth; whereas in equation (4), economic growth Granger causes savings, if $\delta_{j} \neq 0 \forall_{j}$ holds.

\section{Modified Sims Test}

As an alternative to Granger causality test, Sims (1972) developed a causality test based on the general concept of causality that the "future cannot cause the present". This test takes into account the past, current, and future values of regressor to examine the causal link between two variables. Unfortunately, the residuals in the Sims causality test are generally serially correlated. Therefore, eweke, Meese and Dent (1983) proposed to incorporate the lagged dependent variable(s) into the testing equation to overcome the serial correlation problem. The modified Sims test can be performed by estimating the following equations,

$$
\begin{aligned}
& \Delta \ln G_{t}=\alpha+\sum_{i=1}^{p} \lambda_{i} \Delta \ln G_{t-i}+\sum_{j=0}^{q} \delta_{j} \Delta \ln S_{t-j}+\sum_{l=1}^{r} \varphi_{t} \Delta \ln S_{t+t}+\varepsilon_{t t} \\
& \Delta \ln S_{t}=\alpha+\sum_{i=1}^{p} \lambda_{i} \Delta \ln S_{t-i}+\sum_{j=0}^{q} \delta_{j} \Delta \ln G_{t-j}+\sum_{t=1}^{r} \phi_{i} \Delta \ln G_{t+t}+\varepsilon_{2 t}
\end{aligned}
$$

where $\Delta$ is the first difference operator; $p$ and $q$ are the maximum lag order and $r$ represent the maximum lead order. The residuals $\left(\varepsilon_{1 t}, \varepsilon_{2 t}\right)$ are assumed to be white noise and spherically distributed. The different between Sims and modified Sims causality tests is the inclusion 
of lagged dependent variable(s) to remove the serial correlation problem. However, this method is slightly different from the standard Granger causality test, particularly in the testing procedure. In order to examine whether economic growth causes savings, we estimated equation (5) and then employed the $F$-statistic on the null hypothesis of non-causal relation $\left(H_{0}: \varphi_{1}=\varphi_{2}=\right.$ $\left.\ldots=\varphi_{l}=0\right) .{ }^{3}$ If the null hypothesis is rejected, this implies that economic growth causes savings to change. Otherwise, economic growth does not cause savings to change. Inversely, we estimated equation (6) to ascertain the causality from savings to economic growth. If the null hypothesis of noncausal relation $\left(H_{0}: \emptyset_{1}=\varnothing_{2}=\ldots=\emptyset_{l}=0\right)$ is rejected, this asserts that savings causes economic growth to change, otherwise the null hypothesis of savings does not cause economic growth is true.

\section{Hsiao Test}

The literature stated that the Granger causality tests are sensitive to the lag order in the autoregressive process. An inadequate choice of lag length would lead to inconsistent model estimates and the causality inference would likely be misleading. Responding to this, Hsiao (1981) proposed a causality test by combining the Granger concept of causality and information criterions to avoid imposing false and spurious restrictions on the model. ${ }^{4}$ This causality testing approach is based on the idea that the inclusion of causal variable(s) into the estimated model will reduce the size of variation and hence increase the ability to forecast. Hsiao's version of Granger causality test is a two-step procedure to determine the optimal lag lengths and the direction of causality at the same time. In order to ascertain the null hypothesis of savings does not Granger cause economic growth to change, we consider the following model equations,

$$
\Delta \ln G_{t}=\alpha+\sum_{i=1}^{p} \delta_{i} \Delta \ln G_{t-i}+\varepsilon_{1 t}
$$

$$
\Delta \ln G_{t}=\alpha+\sum_{i=1}^{p} \lambda_{i} \Delta \ln G_{t-i}+\sum_{j=1}^{q} \delta_{j} \Delta \ln S_{t-j}+\varepsilon_{2 t}
$$

where $\Delta$ is the first difference operator. The $p$ and $q$ represents the maximum lag order. The error terms $\left(\varepsilon_{1 t}, \varepsilon_{2 t}\right)$ are assumed to be normally distributed and serially uncorrelated. In Hsiao's test, the first step is computing the autoregressive (AR) process model as given by equation (7). Then the Akaike's Information Criterion (AIC) is computed with the order of lags $i$ varying from 1 to $p$. The lag $p$ with the smallest AIC values is chosen and denotes the corresponding $A I C$ as $A I C(p, 0)$.

In the second step, $\Delta 1 \mathrm{n} G_{t}$ is treated as controlled variables with $p$ lags, then lags of $\Delta$ $\ln S_{t}$ are added sequentially into equation (8). After that, the AIC is computed with the order of lags $j$ varying from 1 to $q$. The lag $q$ with the smallest $A I C$ values is chosen and denote the corresponding $A I C$ as $\operatorname{AIC}(p, q)$. According to Hsiao's (1981) interpretation; if AIC $(p, 0)>A I C$ $(p, q)$ then $\Delta \ln S_{t}$ Granger causes $\Delta \ln G_{t}$. On the other hand, if $\operatorname{AIC}(p, 0)<\operatorname{AIC}(p, q)$ then $\Delta \ln S_{t}$ does not Granger cause $\Delta \ln G_{t}$.

\section{Modified Wald (MWALD) Test}

He and Maekawa (2001) argued that $F$-statistics for the Granger causality test often leads to spurious causality inference when one or both of the estimated series are non-stationary. Furthermore, the low power unit root test will always have a degree of uncertainty with respect to the order of integration. Due to this problem, Toda and Yamamoto (1995) proposed a simple procedure (modified Wald - MWALD test) which involves the estimation of an augmented vector autoregression (VAR) model at level irrespective of the order of integration. Thus, pre-testing of unit root is not required in this causality test. In short, the test will conduct with variables at level by adding extra lag $\left(d_{\max }\right)$ into the VAR system 
to ensure that the asymptotic critical values can be applied when the test is conducted between the integrated variables. The $d_{\max }$ refers to the suspected maximum order of integration. Thus, the MWALD testing equation can be expressed as follows,

$\ln S_{t}=\alpha+\sum_{i=1}^{p} \lambda_{i} \ln S_{t-i}+\sum_{j=p+1}^{d_{\text {max }}} \pi_{j} \ln S_{t-j}+\sum_{i=1}^{q} \delta_{i} \ln G_{t-i}+\sum_{j=q+1}^{d_{\text {max }}} \theta_{j} \ln G_{t-j}+\varepsilon_{1 t}$

$\ln G_{t}=\alpha+\sum_{i=1}^{p} \delta_{i} \ln G_{t-i}+\sum_{j=q+1}^{d_{\max }} \theta_{j} \ln G_{t-j}+\sum_{i=1}^{q} \lambda_{i} \ln S_{t-i}+\sum_{j=p+1}^{d_{\text {max }}} \pi_{j} \ln S_{t-j}+\varepsilon_{2 t}$

In order to employ the MWALD test, we have to pre-specify the maximum order of integration $\left(d_{\max }\right)$ for the series in the VAR system. Regarding the extra lag $\left(d_{\max }\right)$ variables, Dolado and Lütkepohl (1996) suggested using $d_{\max }=1$ due to its best performance in their Monte Carlo study. In this respect, we used $d_{\max }=1$ in our study. ${ }^{5}$ Similarly, the $F$-statistic is employed to examine the existence of causal relationship. From equation (9), $\delta_{i} \neq 0_{\forall^{i}}$ asserts that there is causality running from economic growth to savings; whereas in equation (10), savings causes economic growth, if $\lambda_{i} \neq 0_{\forall^{i}}$ holds.

\section{Nonparametric Causality Technique}

Toward this end, our study investigated the savings-growth nexus in Malaysia using nonparametric causality methodology because of its superior statistical properties to the parametric approach. Holmes and Hutton (1988, 1990a) argued that the parametric causality tests (i.e. Granger, Sims, modified Sims, Hsiao, and MWALD) may be problematic compared to nonparametric procedures. This is because the parametric causality approaches are based on the maintained hypotheses of correct functional form, homoskedasticity, the residuals are free from the serial correlation problem, and data are normally distributed. Violation of these classical assumptions will affect the causality inferences (Gordon \& Sakyi-Bekoe, 1993; Ansari, Gordon, \& Akuamoah, 1997; Tang \& Lean, 2008). Thus, Holmes and Hutton (1988, 1990a) proposed an alternative Granger causality testing procedure based on the rank ordering $(R)$ of each variable. That is, they suggested ranking each variable and using the rank value of each observation to test for causality. If the maintained hypothesis is violated this nonparametric approach is robust over the alternative parametric Granger causality test. Holmes and Hutton (1990b) added that the nonparametric approach multiple rank $F$-test is approximately twice as powerful as the parametric approach, when the sample size is small and linear. The multiple rank $F$-test equation can be written as follows:

$$
\begin{aligned}
& R\left(\Delta \ln S_{t}\right)=\alpha+\sum_{i=1}^{p} \lambda_{i} R\left(\Delta \ln S_{t-i}\right)+\sum_{j=1}^{q} \delta_{j} R\left(\Delta \ln G_{t-j}\right)+\varepsilon_{1 t} \\
& R\left(\Delta \ln G_{t}\right)=\alpha+\sum_{i=1}^{p} \delta_{i} R\left(\Delta \ln G_{t-i}\right)+\sum_{j=1}^{q} \lambda_{j} R\left(\Delta \ln S_{t-j}\right)+\varepsilon_{2 t}
\end{aligned}
$$

where $R($.) represents a rank order transformation; $p$ and $q$ refer to the maximum lag length incorporated into the testing equation. The residuals $\varepsilon_{1 t}$ and $\varepsilon_{2 t}$ are assumed to be serially uncorrelated and white noise. Then, the $F$-statistic is employed to examine the possibility of presence of a causal relationship between savings and economic growth. From equation (11), $\delta_{j} \neq 0 \forall_{j}$ implies that there is causality from economic growth to savings; whereas in equation (12), savings causes economic growth, if $\lambda_{j} \neq 0 \forall_{j}$.

Table 1 and Table 2 summarise the five causality testing equation and hypothesis respectively. 
Table 1: Five Types of Causality Testing Model

Types of Causality_ Causality Testing Model

Tests $\quad$ Economic Growth $\left(G_{t}\right)$ causes Savings $\left(S_{t}\right)$ Savings $\left(S_{t}\right)$ causes Economic Growth $\left(G_{t}\right)$

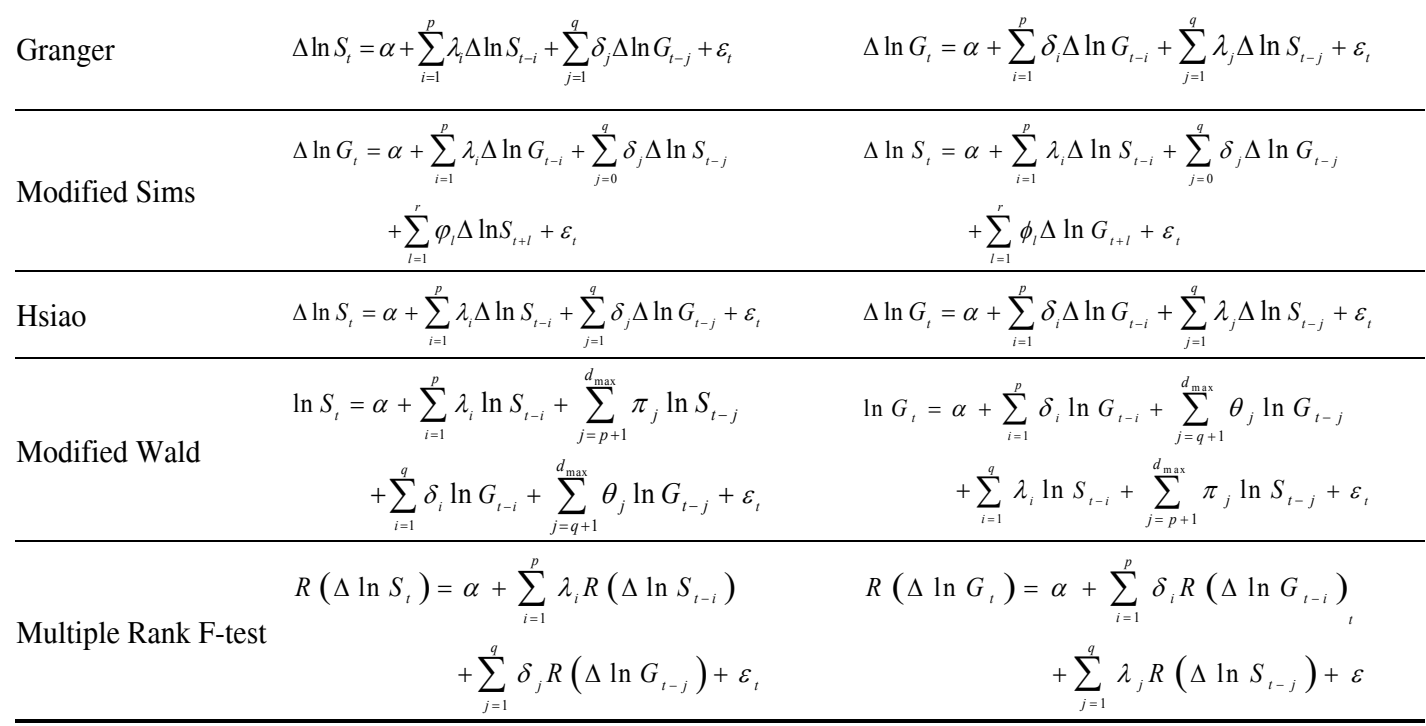

Table 2: Hypothesis Testing and AIC Criteria for Causality in Five Models

\begin{tabular}{|c|c|c|c|c|}
\hline \multirow{2}{*}{ Types of Causality Tests } & \multicolumn{2}{|c|}{ Unidirectional } & \multirow{2}{*}{$\begin{array}{l}\text { Bilateral } \\
S_{t} \leftrightarrow G_{t}\end{array}$} & \multirow{2}{*}{$\begin{array}{l}\text { No Causality } \\
S_{t} \leftrightarrow G_{t} \\
\end{array}$} \\
\hline & $G_{t} \rightarrow S_{t}$ & $S_{t} \rightarrow G_{t}$ & & \\
\hline Granger & $H_{0}: \sum_{j=1}^{q} \delta_{j} \neq 0$ & $H_{0}: \sum_{j=1}^{q} \lambda_{j} \neq 0$ & $\begin{array}{l}H_{0}: \sum_{j=1}^{q} \delta_{j} \neq 0 \\
H_{0}: \sum_{j=1}^{q} \lambda_{j} \neq 0\end{array}$ & $\begin{array}{l}H_{0}: \sum_{j=1}^{q} \delta_{j}=0 \\
H_{0}: \sum_{j=1}^{q} \lambda_{j}=0\end{array}$ \\
\hline Modified Sims & $H_{0}: \sum_{l=1}^{r} \varphi_{l} \neq 0$ & $H_{0}: \sum_{l=1}^{r} \phi_{l} \neq 0$ & $\begin{aligned} H_{0} & : \sum_{l=1}^{r} \phi_{l} \neq 0 \\
H_{0} & : \sum_{l=1}^{r} \varphi_{l} \neq 0\end{aligned}$ & $\begin{aligned} H_{0}: \sum_{l=1}^{r} \phi_{l} & =0 \\
H_{0}: \sum_{l=1}^{r} \varphi_{l} & =0\end{aligned}$ \\
\hline Hsiao & $\begin{array}{l}A I C(\Delta \ln S) \\
>A I C(\Delta \ln S, \Delta \ln G)\end{array}$ & $\begin{array}{l}\operatorname{AIC}(\Delta \ln G) \\
>\operatorname{AIC}(\Delta \ln G, \Delta \ln S)\end{array}$ & $\begin{array}{l}A I C(\Delta \ln S) \\
>A I C(\Delta \ln S, \Delta \ln G) \\
A I C(\Delta \ln G) \\
>A I C(\Delta \ln G, \Delta \ln S)\end{array}$ & $\begin{array}{l}A I C(\Delta \ln S) \\
=A I C(\Delta \ln S, \Delta \ln G) \\
\text { AIC }(\Delta \ln G) \\
=A I C(\Delta \ln G, \Delta \ln S)\end{array}$ \\
\hline Modified Wald & $H_{0}: \sum_{i=1}^{q} \delta_{i} \neq 0$ & $H_{0}: \sum_{i=1}^{q} \lambda_{i} \neq 0$ & $\begin{array}{l}H_{0}: \sum_{i=1}^{q} \delta_{i} \neq 0 \\
H_{0}: \sum_{i=1}^{q} \lambda_{i} \neq 0\end{array}$ & $\begin{array}{l}H_{0}: \sum_{i=1}^{q} \delta_{i}=0 \\
H_{0}: \sum_{i=1}^{q} \lambda_{i}=0\end{array}$ \\
\hline Multiple Rank F-test & $H_{0}: \sum_{j=1}^{q} \delta_{j} \neq 0$ & $H_{0}: \sum_{j=1}^{q} \lambda_{j} \neq 0$ & $\begin{array}{l}H_{0}: \sum_{j=1}^{q} \delta_{j} \neq 0 \\
H_{0}: \sum_{j=1}^{q} \lambda_{j} \neq 0\end{array}$ & $\begin{array}{l}H_{0}: \sum_{j=1}^{q} \delta_{j}=0 \\
H_{0}: \sum_{j=1}^{q} \lambda_{j}=0\end{array}$ \\
\hline
\end{tabular}




\section{EMPIRICAL RESULTS}

According to Granger and Newbold (1974), and Phillips (1986) the regression result may be spurious if the estimated variables are nonstationary. Thus, prior to Granger causality tests, it is necessary for this study to perform the unit root test to avoid the spurious causality problem. In this study, we carried out the KPSS unit root test to determine the order of integration for each series. The KPSS test results are reported in Table 3 , and revealed that the two interested variables ( $\ln S_{t}$ and $\ln G_{t}$ ) are non-stationary at level or integration of order one, $I(1)$, i.e., both series are stationary in first difference form $\left(\Delta \ln S_{t}\right.$ and $\left.\Delta \ln G_{t}\right)$. These results supported the Nelson and Plosser (1982) notion that most of the macroeconomic series are non-stationary at level but become stationary after first differencing. With these findings we can proceed to the causality tests with the first difference variables (except for the MWALD causality test) to examine the causal relationship between savings and economic growth in Malaysia.

Table 3: The Results of KPSS Unit Root Test

\begin{tabular}{llc}
\hline & \multicolumn{2}{c}{ Test statistics } \\
\cline { 2 - 3 } Variables & $\eta_{u}$ & $\eta_{\tau}$ \\
\hline Level: & & $0.148^{* *}$ \\
$\ln S_{t}$ & $0.976^{*}$ & $0.216^{*}$ \\
$\ln G_{t}$ & $0.942^{*}$ & \\
First difference: & & $0.150^{* * *}$ \\
$\Delta \ln S_{t}$ & 0.160 & $0.143^{* * *}$ \\
$\Delta \ln G_{t}$ & 0.250 &
\end{tabular}

Note: The asterisks **** and $* * *$ denote the significance at $1 \%, 5 \%$, and $10 \%$ levels respectively. The $\eta$ statistics refer to the KPSS test the stationarity null hypothesis against the alternative hypothesis of a unit root. The subscripts $\mu$ and $\tau$ indicate the models that allow for drift terms and both a drift and deterministic trend respectively. The following asymptotic critical values are obtained from Kwiatkowski et al. (1992).

$\begin{array}{lll}\text { Significance Level: } & \text { Level: } & \text { Trend: } \\ 1 \% & 0.739 & 0.216 \\ 5 \% & 0.463 & 0.146 \\ 10 \% & 0.437 & 0.119\end{array}$

Thornton and Batten (1985) postulated that causality tests are very sensitive to the lag structure incorporated into the testing equations as different lag structures may produce different causality results. In most time series analyses, estimating optimal lag structure is a crucial econometric exercise. It is also well known that most of the economic series are time series in nature and follow the autoregressive process. Koutsoyiannis (1977) documented that in a time series analysis, the parameters are implausible to be estimated when there are large numbers of lags in a small sample as there will be an inadequate degree of freedom to carry out the traditional statistical tests. Furthermore, it is almost certain that multicollinearity problems will arise and this will cause the statistical test to be insignificant at the conventional critical level. According to Enders (2004), too few lags in a regression model may cause the regression residuals not to behave like white noise. On the other hand, too many lags in a regression model will reduce the forecasting performance of the fitted model. If quarterly data is used, he suggested to begin with 12 lag as a maximum lag structure. Therefore, the present study performed a series of lag structure sequentially from 12 to 1 and the Akaike's Information Criterion (AIC) was used to choose the optimal lag structure owing to its superior performance in a small sample study (Liew, 2004). The calculated F-statistics for causality tests together with the optimal lag structure are reported in Table 4. At the $10 \%$ significant level, we found that both the parametric and nonparametric causality tests consistently reject the null hypotheses of non-causal link between savings and economic growth in Malaysia over the analysis period. This indicated that savings and economic growth in Malaysia Granger causes each other (i.e. bilateral causality) regardless of the causality tests used. 
Table 4: The Results of Five Causality Tests

\begin{tabular}{|c|c|c|c|c|c|c|c|c|c|}
\hline \multirow{2}{*}{$\begin{array}{c}\text { Type of } \\
\text { Causality Test }\end{array}$} & \multicolumn{4}{|c|}{$S_{t} \rightarrow G_{t}$} & \multicolumn{4}{|c|}{$G_{t} \rightarrow S_{t}$} & \multirow{2}{*}{ Causal Inference } \\
\hline & Lag & Lead & F-Statistics & Minimum AIC & Lag & Lead & F-Statistics & Minimum AIC & \\
\hline Granger & 5 & - & $2.583 * *$ & - & 11 & - & $4.169^{*}$ & - & $S_{t} \leftrightarrow G_{t}$ \\
\hline Modified Sims & 4 & 4 & $2.469 * * *$ & - & 4 & 4 & $2.581^{* *}$ & - & $S_{t} \leftrightarrow G_{t}$ \\
\hline Hsiao - AIC & $(5,12)$ & - & - & $(-4.21>-4.31)$ & $(12,11)$ & - & - & $(-2.50>-2.88)$ & $S_{t} \leftrightarrow G_{t}$ \\
\hline Modified Wald & 6 & - & $2.818^{* *}$ & - & 12 & - & $3.021 *$ & - & $S_{t} \leftrightarrow G_{t}$ \\
\hline Multiple Rank F-test & 12 & - & $2.571 * *$ & - & 12 & - & $2.099 * * *$ & - & $S_{t} \leftrightarrow G_{t}$ \\
\hline
\end{tabular}

Note: The asterisks *,** and $* * *$ denotes the significance at $1 \%, 5 \%$, and $10 \%$ levels respectively. Each of the lag and lead in the VAR system are selected by Akaike's information criterion (AIC). We use $d_{\max }=1$ for MWALD test. The unequal lag order is used in the Hsiao's causality test.

The consistent bilateral causality evidence from the five causality tests highlighted two remarkable points: firstly, using different causality techniques may not yield different causality inferences. Thus, our empirical evidence showed that causality technique plays no role in explaining the inconsistent causal link between savings and economic growth. This evidence contradicted Chowdury's (1987) postulation. A plausible explanation for the contrary result is that Chowdury (1987) did not take into account the optimal lag structure accommodated into the VAR system, thus causality results may differ. In view of literature, the financial system in Malaysia has undergone a remarkable transformation in terms of range of institutions in the system of commercial banks to unit trusts, merchant banks, and discount houses. The progress in the development of the Malaysian financial structure has also reflected the effectiveness of the financial section in mobilising savings. In addition to that, the government formed the Post Office Bank and National Savings Bank to mobilise savings from the small depositors in the rural areas. Therefore, the evidence of a bilateral causal relationship between savings and economic growth in Malaysia is not a surprising phenomenon.

Secondly, since the five causality tests are consistently suggesting that savings is an engine for economic growth in Malaysia, we may surmise that the financial system in Malaysia has successfully translated savings into productive sectors which foster economic growth. Therefore, mobilising domestic saving is helpful rather than harmful to the Malaysian economy. In addition, this result corroborates with the findings of Tang (2008) that savings and economic growth for Malaysia Granger causes each other.

\section{CONCLUDING REMARKS}

This study employed various causality tests to detect the causal relationship between savings and economic growth in Malaysia. In particular, this study attempted to investigate whether the causal inference between savings and economic growth in Malaysia is sensitive to the particular causality test employed to ascertain the causal relationship. A remarkable finding emerged from this study is that the causality test results consistently suggest a bilateral causal relationship between savings and economic growth in Malaysia over the period of 1991:Q1 to 2006:Q3. This implied that the causal relationship between savings and economic growth in Malaysia is not sensitive to the particular causality test used in testing for causality. In other words, this study found that causality technique does not affect the causality results between savings and economic growth in Malaysia, thus the inconsistency of savings-growth nexus for Malaysia is not a result of the type of causality test. Interestingly, the causality test results has consistently affirmed that savings is a prominent 
source for economic growth in Malaysia, hence mobilising the domestic resources, such as savings, is of paramount importance for further economic development in Malaysia. This finding is consistent with Lewis (1955) and endogenous growth theory which postulated that higher the savings rate will increase the rate of investment, which eventually leads to economic development and growth.

\section{END NOTES}

1 In this article, Southeast Asia refers to Indonesia, Malaysia, the Philippines, Singapore and Thailand.

2 In our study, we used parametric (i.e. Granger model, Hsiao model, modified Sims model, and MWALD) and nonparametric (i.e. Multiple F-rank) tests to examine the possibility of presence causal link between savings and economic growth in Malaysia quation (6) will be estimated if the standard Granger causality test is adopted.

4 The standard Hsiao's test uses the Final Prediction Error (FPE) to draw the conclusion, but in this study we preferred to use Akaike's Information Criterion (AIC) due to it simplicity.

5 Some of the existing studies used unit root test to identify the order of $d_{\text {max }}$.

\section{ACKNOWLEDGEMENT}

This research work was funded by USM Fellowship, University Sains Malaysia.

\section{REFERENCES}

Agrawal, P. (2001). The relation between saving and growth: Cointegration and causality evidence from Asia. Applied Economics, 33, 499-513.

Alguacil, M., Cuadros, A., \& Orts, V. (2004). Does saving really matter to growth? Mexico (1970-2000). Journal of International Development, 16(2), 281-290.
Ansari, M.I., Gordon, D.V., \& Akuamoah, C. (1997). Keynes versus Wagner: Public expenditure and national income for three African countries. Applied Economics, 29, 543-550.

Baharumshah, A.Z., Thanoon, M.A., \& Rashid, S. (2003). Saving dynamics in the Asian countries. Journal of Asian Economics, 13(6), 827-845.

Campbell, J.Y., \& Perron, P. (1991). Pitfalls and opportunities: What macroeconomists should know about unit roots, National Bureau of Economic Research, Macroeconomics Annual, MIT Press, Cambridge, MA, 141-201.

Carroll, C.D., Overland, J., \& Weil, D.N. (2000). Saving and growth with habit formation. American Economic Review, 90, 341-355.

Chowdury, R.A. (1987). Are causal relationship sensitive to causality tests? Applied Economics, 19, 459-465.

DeJong, D.A., Nankervis, J.C., Savin, N.E., \& Whiteman, C.H. (1992). Integration versus trend stationarity in time series. Econometrica, 60, 423-433.

Dolado, J.J., \& Lütkepohl, H. (1996). Making wald tests work for cointegrated VAR system. Econometric Reviews, 15, 369-386.

Enders, W. (2004). Applied econometric time series (2nd ed.). United States of America: John Wiley \& Sons.

Granger, C.W.J. (1969). Investigating causal relations by econometric models and cross-spectral methods. Econometrica, 37, 428-438.

Granger, C.W.J., \& Newbold, P. (1974). Spurious regression in econometrics. Journal of Econometrics, 2, 111-120.

Gordon, D.V., \& Sakyi-Bekoe, K. (1993). Testing the export-growth hypothesis: Some parametric and nonparametric results for Ghana. Applied Economics, 25, 553-563.

Geweke, J., Meese, R., \& Dent, W. (1983). Comparing alternative tests of causality in temporal systems. Journal of Econometrics, 21, 161-194.

Gruben, W., \& McLeod, D. (1998). Capital flows savings and growth in the 1990s. Quarterly Review of Economics and Finance, 38, 287. 
Harrod, R.F. (1939). Toward a dynamic economics. London: Macmillan.

He, Z., \& Maekawa, K. (2001). On spurious granger causality. Economics Letters, 73(3), 307-313.

Hsiao, C. (1981). Autoregressive modeling and money-income causality detection. Journal of Monetary Economics, 7, 85-106.

Holmes, J.M., \& Hutton, P.A. (1988). A functionalform distribution-free alternative to parametric analysis of Granger causal models. Advances in Econometrics, 7, 211-225.

Holmes, J.M., \& Hutton, P.A. (1990a). On the causal relationship between government expenditure and national income. Reviews of Economics Statistics, 72(1), 87-95.

Holmes, J.M., \& Hutton, P.A. (1990b). Small sample properties of the multiple rank F-test with lagged dependent variables. Economics Letters, 33, 55-61.

Koutsoyiannis, A. (1977). Theory of econometric: An introductory exposition of econometric (2nd ed.). London: The MacMillan Press.

Kwiatkowski, D., Phillips, P.C.B., Schmidt, P., \& Shin, Y. (1992). Testing the null of stationarity against the alternative of a unit root: How sure are we that the economic time series have a unit root? Journal of Econometrics, 54, 159-178.

Lee, H.Y., Lin, K.S., \& Wu, J.L. (2002). Pitfalls in using granger causality tests to find an engine of growth. Applied Economics Letters, 9, 411-414.

Levine, R., \& Renelt, D. (1992). A sensitivity analysis of cross countries growth regression. American Economic Review, 82, 942-963.

Lewis, W.A. (1955). Theory of economic growth. London: Allen and Unwin.

Liew, K.S. (2004). Which lag length selection criteria should we employ? Economics Bulletin, 3(33), 1-9.
Mankiw, N.G., Romer, D., \& Weil, D.N. (1992). A contribution to empirics of economic growth. Quarterly Journal of Economic, 11, 681-712.

Nelson, C.R., \& Plosser, C.I. (1982). Trends and random walks in macroeconomics time series. Journal of Monetary Economics, 10, 139-162.

Phillips, P.C.B. (1986). Understanding spurious regressions in econometrics. Journal of Econometrics, 33(3), 311-340.

Rodrik, D. (2000). Saving transitions. The World Bank Economic Review, 14, 481-507.

Sims, C.A. (1972). Money, income and causality. American Economic Review, 62, 540-552.

Sinha, D., \& Sinha, T. (1998). Cart before the horse? The saving-growth nexus in Mexico. Economics Letters, 61, 43-47.

Tang, C.F. (2008). An empirical modelling on savings behaviour in Malaysia. Labuan Bulletin of International Business \& Finance, 6, 57-76.

Tang, C.F., \& Lean, H.H. (2008). New evidence from the misery index in the crime function. Economics Letters, DOI: 10.1016/j. econlet.2008.11.026.

Thornton, D.L., \& Batten, D.S. (1985). Lag-length selection and tests of Granger causality between money and income. Journal of Money, Credit, and Banking, 17(2), 164178.

Toda, H.Y., \& Yamamoto, T. (1995). Statistical inference in vector autoregressions with possibly integrated processes. Journal of Econometrics, 66, 225-250.

$\mathrm{Xu}, \mathrm{Z}$. (1996). On the causality between export growth and GDP growth: An empirical re-investigation. Review of International Economics, 4, 172-184.

Zhou, S. (2001). The power of cointegration tests versus data frequency and time spans. Southern Economic Journal, 67(4), 906921. 